\title{
A szorongás és a diabetes közti kapcsolat
}

\author{
Hargittay Csenge dr. ${ }^{1}$. Gonda Xénia dr. ${ }^{2}$ \\ Márkus Bernadett dr. ${ }^{1}$ - Sipkovits Zsófia ${ }^{1}$ - Vörös Krisztián dr. ${ }^{1}$ \\ Kalabay László dr. ${ }^{1}$ - Rihmer Zoltán dr. ${ }^{2}$. Torzsa Péter dr. ${ }^{1}$ \\ 'Semmelweis Egyetem, Általános Orvostudományi Kar, Családorvosi Tanszék, Budapest \\ ${ }^{2}$ Semmelweis Egyetem, Általános Orvostudományi Kar, \\ Pszichiátriai és Pszichoterápiás Klinika és Országos Pszichiátriai és Addiktológiai Intézet, Budapest
}

\begin{abstract}
A cukorbetegség és a depresszió kapcsolatáról számos tanulmány született. A szorongás és a diabetes közti összefüggést már kevesebben vizsgálták, pedig jelentős szerepük van a szorongásos kórképeknek is, hiszen nagyon gyakori a két betegség együttes előfordulása. A diabetes már önmagában is nagy betegségterhet jelent a betegek számára, a társuló pszichiátriai kórképek pedig tovább rontják a kezelés minőségét, ezért fontos a korai felismerésük és kezelésük. Jelen összefoglaló közleményünk célja a szorongásos kórképek és elsősorban a 2-es típusú cukorbetegség közti összefüggés feltárása. Több elmélet született a köztük lévő kapcsolat magyarázatára. Egyesek szerint szerepet játszhat benne a közös etiológiai háttér, mások szerint a cukorbetegség diagnózisa és a gondozásával kapcsolatos feladatok vezetnek szorongáshoz. Megint mások pedig ellentétes irányból vizsgálva a köztük lévő kapcsolatot, arra a megállapításra jutottak, hogy a szorongás különböző fiziológiai mechanizmusokon keresztül vezethet cukorbetegséghez. A szorongás és a diabetes közti kapcsolat irányától függetlenül javasolt a depresszió mellett a szorongásnak a szűrése és minél korábbi kezelése a cukorbetegek körében, így csökkennének a komorbiditásból származó szövődmények, a kezelési nehézségek, javulna a betegek életminősége és a terápiával való együttmúködésük.

Orv Hetil. 2021; 162(31): 1226-1232.
\end{abstract}

Kulcsszavak: 2-es típusú diabetes mellitus, szorongás, komorbiditás

\section{The relationship between anxiety and diabetes}

The relationship between diabetes and depression has been evaluated in numerous studies. The association between diabetes and anxiety was less investigated, although the importance of anxiety disorders is underlined by its frequent co-occurrence with diabetes. Diabetes alone carries a significant disease burden for patients. Comorbidity with psychiatric disorders deteriorates the quality of care, therefore early treatment and diagnosis of these conditions are essential. The aim of the present review is to outline the relationship between anxiety and mainly type 2 diabetes. There are several theories to explain the relationship between them. Some researchers suggest that common etiological background may play a role in their co-occurrence, some believe that the diagnosis of diabetes and the burden of self-management lead to anxiety, while others - investigating the relationship from the opposite direction - suggest that anxiety leads to diabetes through physiological mechanisms. Independently of the direction of the relationship, screening for anxiety and timely treatment among diabetic patients may decrease the risk of complications, the difficulty in treatment arising from the co-occurrence of these two conditions and may improve patients' quality of life and adherence to therapy.

Keywords: type 2 diabetes mellitus, anxiety, comorbidity

Hargittay Cs, Gonda X, Márkus B, Sipkovits Zs, Vörös K, Kalabay L, Rihmer Z, Torzsa P. [The relationship between anxiety and diabetes]. Orv Hetil. 2021; 162(31): 1226-1232.

(Beérkezett: 2021. január 8.; elfogadva: 2021. február 2.)

\section{Rövidítések}

5-HTTLPR = (serotonin transporter-linked polymorphic region) szerotonintranszporterhez kapcsolt polimorf régió; ADA $=($ American Diabetes Association $)$ Amerikai Diabetes Társa- ság; $\mathrm{BAI}=($ Beck Anxiety Inventory $)$ Beck Szorongás Skála; $\mathrm{CI}=($ confidence interval $)$ megbízhatósági tartomány; DDS = (Diabetes Distress Scale) Diabetes Distressz Skála; DSM = (Diagnostic and Statistical Manual of Mental Disorders) Men- 
tális betegségek diagnosztikai és statisztikai kézikönyve; HAM-A = (Hamilton Anxiety Scale) Hamilton Szorongás Skála; HPA = (hypothalamic-pituitary-adrenal) hypothalamus-hypophysis-mellékvese; IDF = (International Diabetes Federation) Nemzetközi Diabetes Szövetség; MINI = (Mini International Neuropsychiatric Interview) Mini Nemzetközi Neuropszichiátriai Interjú; $\mathrm{OR}=$ (odds ratio) esélyhányados; PAID $=($ Problem Areas in Diabetes $)$ Problémás Területek a Cukorbetegségben; STAI $=$ (Spielberger State and Trait Anxiety Inventory) Spielberger Állapot- és Vonásszorongás Kérdő́ív; TNF $\alpha=$ tumornekrózisfaktor-alfa; WHO = (World Health Organization) Egészségügyi Világszervezet

A szorongás szabadon lebegő félelemmel, negatív érzelmekkel járó állapot, amely mindig összekapcsolódik valamilyen veszély anticipációjával. Ha a szorongás már gátolja a mindennapi feladatok elvégzését, rontja az életminőséget, vagy szenvedést okoz, felmerül a szorongásos zavar diagnózisa. A szorongás a különféle pszichés betegségekben különféle formákban manifesztálódik. A szorongásos zavarok közé tartozik a pánikzavar, az agorafóbia, a szociális szorongásos zavar, a specifikus fóbia és a generalizált szorongás. A DSM (Diagnostic and Statistical Manual of Mental Disorders, Mentális betegségek diagnosztikai és statisztikai kézikönyve) 5 . kiadásában a kényszerbetegség és a poszttraumás stresszzavar nem a szorongásos zavarok között szerepel, ugyanakkor bekerült a szelektív mutismus és a szeparációs szorongás, amelyek a IV. kiadásban még külön, a gyermekkori kezdetû́ zavarok között szerepeltek [1].

A szorongásos zavarok a leggyakrabban előforduló pszichiátriai kórképek közé tartoznak. Az Egészségügyi Világszervezet (World Health Organization, WHO) becslése szerint 264 millió embert (a populáció 3,6\%-a) érint a világon, és a hatodik helyen áll a nem végzetes egészségkárosodáshoz vezető betegségek között [2]. A szorongásos betegségek élettartam-prevalenciája $14,5-33,7 \%$, egyéves prevalenciája 8,4-21,3\% [3]. Hazai vizsgálat alapján az élettartam-prevalencia $18 \%$, a pontprevalencia $8 \%$ volt [4]. Egy Európában végzett felmérés szerint a szorongásos kórképek egyéves prevalenciája 14,0\% volt, és a következőképpen oszlott meg: pánikbetegség $1,8 \%$, agorafóbia $2 \%$, szociális fóbia $2,3 \%$, generalizált szorongás $1,7-3,4 \%$, specifikus fóbiák $6,4 \%$, kényszerbetegség $0,7 \%$, poszttraumás stresszzavar $1,1-2,9 \%$ [5]. Egy, az alapellátásban történt vizsgálat $(\mathrm{n}=965)$ eredményei alapján a poszttraumás stresszzavar $8,6 \%$ ban, a generalizált szorongás 7,6\%-ban, a pánikbetegség 6,8\%-ban, a szociális fóbia 6,2\%-ban fordult elő [6].

A szorongásos zavarokhoz hasonlóan a diabetes is gyakori, népbetegségnek tekinthető. A Nemzetközi Diabetes Szövetség (International Diabetes Federation, IDF) 2019-ben megjelent becslése szerint a világon 463 millió embert érint. Szintén az IDF becslése szerint, hazánkban a cukorbetegség prevalenciája a 20-79 év közötti korosztályban 9,3\%. A cukorbetegek számát 684500 före becsülik [7]. A WHO 2016-ban megjelent Globális Diabetes Jelentésében (Global Report on Diabetes) közzétett magyarországi országprofilja szerint diabetes a halál direkt oka az esetek $2 \%$-ában [8]. A korábbi Országos Egészségbiztosítási Pénztár (jelenleg Nemzeti Egészségbiztosítási Alapkezelő) adatbázisának 2014-es elemzése alapján 727000 fót kezeltek valamilyen antidiabetikummal 2 -es típusú cukorbetegség miatt, ami a teljes lakosságra vonatkoztatva 7,3\%-os előfordulást jelent. A korra és nemre standardizált prevalencia

1. táblázat | Demográfiai adatok és a szorongás prevalenciája 2-es típusú cukorbetegek körében, Európa néhány országában

\begin{tabular}{|c|c|c|c|c|}
\hline Vizsgálat & Betegszám & $\begin{array}{l}\text { A szorongás } \\
\text { diagnózisa }\end{array}$ & Életkor, a nemek aránya & $\begin{array}{l}\text { A szorongás } \\
\text { prevalenciája }\end{array}$ \\
\hline Bouwman V, et al. 2010 (Hollandia) [13] & 2667 & HADS & $\begin{array}{l}\text { 40-65 év közöttiek; } \\
53 \% \text { nő }\end{array}$ & $19,9 \%$ \\
\hline Degmečić D, et al., 2014 (Horvátország) [14] & $\begin{array}{l}\text { 108, ebből } 66 \text { 2-es típusú } \\
\text { cukorbeteg }\end{array}$ & HAM-A & $\begin{array}{l}\text { 61,11 (44-78) év; } \\
42 \% \text { nő }\end{array}$ & $51,5 \%$ \\
\hline Hermanns N, et al. 2005 (Németország) [15] & $\begin{array}{l}\text { 420, ebből } \\
36,9 \% \text { 1-es típusú, } \\
\text { 63,1\% 2-es típusú } \\
\text { cukorbeteg }\end{array}$ & STAI & $\begin{array}{l}\text { 18-75 év közöttiek; } \\
38,4 \% \text { nő }\end{array}$ & $25,2 \%$ \\
\hline Indelicato L, et al., 2017 (Olaszország) [16] & 172 & BAI & $\begin{array}{l}64(58-69) \text { év; } \\
40 \% \text { nó }\end{array}$ & $14,5 \%$ \\
\hline Lewko J, et al. 2012 (Lengyelország) [17] & 126 & HADS & $\begin{array}{l}\text { Férfiak: } 58,8 \pm 10,1 \text { év } \\
\text { Nók: } 66,5 \pm 9,5 \text { év; } \\
59 \% \text { nő }\end{array}$ & $30,4 \%$ \\
\hline Mikaliūkštienè A, et al., 2014 (Litvánia) [18] & 1022 & HADS & $\begin{array}{l}59,3 \text { év; } \\
63,6 \% \text { nő }\end{array}$ & $42,4 \%$ \\
\hline Naicker K, et al. 2017 (Norvégia) [19] & $\begin{array}{l}64 \text { 177, ebból } 1133 \text { 2-es } \\
\text { típusú cukorbeteg }\end{array}$ & $\begin{array}{l}\text { Elektronikus, } \\
\text { egészségügyi adatok }\end{array}$ & 68,31 év; $50,4 \%$ nô & $10,0 \%$ \\
\hline
\end{tabular}

BAI = Beck Szorongás Skála; HADS = Kórházi Szorongás és Depresszió Skála; HAM-A = Hamilton Szorongás Skála; STAI = Spielberger Állapotés Vonásszorongás Kérdőív 
4,2\%-ról 6,4\%-ra nőtt 2001 és 2014 között. Az előfordulási gyakoriság az életkor előrehaladtával emelkedik: a 61-70 évesek körében 2011-ben 19,0\%, a 70 év felettiek között pedig 20,0\% volt [9]. A prevalencia 2016-ban a teljes lakosságra vonatkoztatva közel hasonló volt, 7,27\% (férfiak: 6,93\%, nők: 7,59\%), és az életkor előrehaladtával szintén emelkedett az előfordulási gyakoriság [10].

Irodalmi adatok alapján a szorongásos zavarok gyakrabban fordulnak elő cukorbetegek körében. Egy 12 vizsgálatot feldolgozó metaanalízisben $(\mathrm{n}=12$ 626) 1-es és 2-es típusú cukorbetegekben vizsgálták a szorongásos kórképek és tünetek előfordulását, amelyek 25\%-kal (OR: 1,25 [1,10-1,39]) gyakoribbak voltak a diabeteses betegekben a kontrollcsoporthoz képest [11]. Egy 15 ország közremúködésével létrejött nemzetközi tanulmányban ( $\mathrm{n}=3170$, átlagéletkor $=53,43$ év, 56,2\% nő) a szorongásos zavarok prevalenciája $18 \%$ volt 2-es típusú cukorbetegek körében MINI (Mini International Neuropsychiatric Interview, Mini Nemzetközi Neuropszichiátriai Interjú) kérdőívvel mérve. A leggyakoribb zavar a generalizált szorongás $(8,5 \%)$ és a pánikzavar $(5,1 \%)$ volt. A vizsgált populációban 2,8\%-ban találtak egynél több szorongásos zavart. A szorongás előfordulása Ukrajnában, Szaúd-Arábiában és Argentínában volt a legmagasabb $(72,7 \%, 52,2 \%, 37,6 \%)$, és a legalacsonyabb Indiában és Bangladesben $(0,5 \%, 0,0 \%)$. Európa országait tekintve Németországban 12,7\%, Olaszországban 8,9\%, Lengyelországban 16,6\%, Szerbiában 2,5\% volt. $\mathrm{Az}$ országok közti különbségek okai lehetnek a szorongásos tünetek észlelésének kulturális különbségei, a mentális betegség miatti stigmatizáció és az egyes országokban a prevenció támogatására a családoknak felajánlott széles körü társadalmi támogatás [12].

A cukorbetegek körében előforduló szorongás prevalenciáját számos tényező befolyásolhatja, így a vizsgálat jellege (keresztmetszeti, hosszmetszeti), a vizsgálatba bevont betegek életkora, a nemek aránya, a cukorbetegség fennállásának ideje, a diabetes és a szorongás diagnosztizálásának módja, illetve kritériumai, valamint a cukorbetegséggel komorbid betegségek és a diabetes szövődményeinek jelenléte. Az 1. táblázatban Európa néhány országában a 2-es típusú cukorbetegek körében végzett keresztmetszeti tanulmányok demográfiai adatai és a körükben előforduló szorongás prevalenciája látható. Az előfordulási gyakoriság Kelet-Közép-Európában magasabb volt, 25,2-51,5\%, Észak-, Dél- és NyugatEurópában pedig alacsonyabb, 10,07-19,9\% [13-19].

Fontos a cukorbetegek körében a szorongásos zavarok felismerése, mert a két betegség komorbiditása esetén nő a mortalitás [19], a cukorbetegség szövődményeinek száma, emelkedhet a vércukorszint, rosszabb a betegek életminősége, gyakoribb a depresszió, az elhízás, és nő a fogyatékkal élők száma [11].

Jelen összefoglaló közleményünkben a diabetes és a szorongás közti kapcsolat bemutatása mellett szeretnénk felhívni a figyelmet arra, hogy a 2-es típusú cukorbetegek körében a depresszió mellett a szorongás szúrése is rendkívül fontos.

\section{Módszerek}

A keresést a Scopus, Web of Science, PubMed adatbázisokban végeztük 2020. május 1. és 2020. december 15 . között diabetes mellitus, type 2 diabetes, anxiety, anxiety disorders, bidirectional, association, comorbidity kulcsszavakkal. Elsősorban az utóbbi 5 év közleményeire hivatkoztunk, illetve az ennél régebbi, gyakran citált publikációkra. A keresést magyar nyelvü szakkönyvfejezetek és szakfolyóiratcikkek átolvasásával egészítettük ki. A szakirodalomból metaanalíziseket és szisztematikus öszszefoglaló közleményeket, randomizált kontrollált vizsgálatokat, kohorszvizsgálatokat és keresztmetszeti elemzéseket választottunk.

\section{A cukorbetegség és a szorongás közti kapcsolatot magyarázó elméletek}

A szorongás és a diabetes közti kapcsolat vizsgálatáról kevesebb tanulmány született, mint a depresszió és a cukorbetegség összefüggéséről. A két betegség közti kapcsolatban szerepe lehet a közös etiológiai háttérnek, de lehetséges, hogy a köztük lévő összefüggés kétirányú: a szorongás szerepet játszik a diabetes kialakulásában és fordítva, a cukorbetegség befolyásolhatja a szorongásos zavarok kialakulását.

\section{Közös etiológiai háttér}

Mindkét betegség kialakulásában szerepe lehet genetikai tényezőknek és környezeti hatásoknak. A szerotonintranszporter gén polimorfizmusának a depresszióban és a szorongásban játszott szerepe jól ismert [20]. A szerotonintranszporter gén (SLC6A4) promoter régiója szabályozza a szerotonintranszporter fehérje (5-HTT) átírását. Ennek a régiónak egyik polimorfizmusa az 5-HTTLPR (serotonin transporter-linked polymorphic region) variáns. Két változata létezik, a hosszú (long) Lés a rövid (short) S-allél. A stressz következtében kialakuló depresszió az egy, de inkább a két S-allélt örökölt személyek esetén gyakoribb [21].

A szerotonintranszporter gén polimorfizmusa és a 2-es típusú cukorbetegség közötti kapcsolatra vonatkozóan ellentmondásos vizsgálati eredmények születtek. Szoros összefüggést találtak egy vizsgálatban a rövid allél (5-HTTLPR LS, SS genotípusok) és a 2-es típusú cukorbetegség között $(\mathrm{OR}=2,14)$; az elhízással nem találtak összefüggést [22]. Mások nem találtak szignifikáns öszszefüggést a szerotonintranszporter gén polimorfizmusa és a 2-es típusú cukorbetegség kialakulása között $[23,24]$. A fent említett ellentmondásos eredményeket 
magyarázhatja a cukorbetegség genetikai hátterének eltérése a különböző populációkban.

Egerekben történt vizsgálat alapján felmerült, hogy a szerotonintranszporter genotípus szerepet játszhat a cukorbetegek stressz-szabályozásában. Sztreptozocin kiváltotta l-es típusú diabetes esetében csökkent a stresszre adott szerotoninválasz a prefrontális kéregben [25].

Egy, a 2-es típusú cukorbetegek körében végzett tanulmányban az 5-HTTLPR-genotípus és a szorongás, illetve depresszió diagnózisának kezdete, a depresszió súlyossága és a pszichológiai distressz közti kapcsolatot vizsgálták. A 2-es típusú cukorbetegek körében (mint olyan betegeknél, akiknél a krónikus betegség miatt krónikus stressz áll fenn) az 5-HTTLPR-genotípus a pszichológiai distresszel mutatott szignifikáns összefüggést, a többi vizsgált paraméterrel nem [26].

A két betegség közös genetikai hátterének vizsgálatával kapcsolatban, a fent bemutatott ellentmondásos eredmények miatt, további tanulmányokra van szükség, de a közös etiológiai hátteret tovább vizsgálva fontos tényező lehet még az alacsony társadalmi-gazdasági helyzet, ami egyaránt növeli a cukorbetegség és a szorongás kialakulásának kockázatát [27, 28].

\section{A szorongás hatása a cukorbetegség kialakulására}

A két betegség közti összefüggést vizsgálva felmerül, hogy a kapcsolat kétirányú. A stressz okozhat cukorbetegséget, és a diabetes is vezethet szorongáshoz. Egy metaanalízisben az 1 -es és 2-es típusú cukorbetegség és a szorongás közti hosszmetszeti összefüggést tanulmányozták. Eredményeik alapján a szorongásos tünetek és zavarok megléte esetén nagyobb volt az esélye $(\mathrm{OR}=$ 1,47; CI 1,23-1,75) a cukorbetegség kialakulásának. Az összefüggés egyéb szociodemográfiai, kardiometabolikus és elhízással kapcsolatos tényezőkre történő illesztés után is fennállt [29].

$\mathrm{Az}$ érzelmi stressz hathat a betegek viselkedésére, alvászavarhoz és egészségtelen életmódbeli szokásokhoz vezethet, mint a nem megfelelő táplálkozás, a kevés mozgás, az elhízás, a dohányzás és az alkoholfogyasztás, amelyek a cukorbetegség kialakulásának jól ismert rizikótényezői [30-34].

A fentieken kívül fiziológiai mechanizmusokon keresztül is kialakulhat a cukorbetegség. Kutatások alapján a szorongás a hypothalamus-hypophysis-mellékvese (hypothalamic-pituitary-adrenal, HPA) tengely aktiválódása által vezethet cukorbetegséghez. A krónikus szorongás aktiválja a HPA-tengelyt és a szimpatikus idegrendszert, megemelkedik a glükagon, az adrenalin, a noradrenalin, a kortizol és a növekedési hormon szintje, aminek hatására emelkedik a vércukorszint, és inzulinrezisztencia, visceralis obesitas, metabolikus szindróma, végül 2-es típusú diabetes mellitus alakul ki [35].

Mind a szorongásos zavarokban, mind diabetesben megfigyelhető az immunrendszer múködési zavara és a gyulladásos citokinek termelődésének növekedése. A tartós stressz befolyásolja az immunrendszer múködését, emelkedik a tumornekrózisfaktor-alfa $(\mathrm{TNF} \alpha)$ és az interleukin-6 szintje [36]. Ezek a gyulladásos paraméterek hatnak a hasnyálmirigy béta-sejtjeire és az adipocytákra, ami béta-sejt-múködési zavarhoz, inzulinrezisztenciához, majd 2-es típusú cukorbetegséghez vezet [37]. A szorongó betegek reggeli kortizolszintje alacsonyabb $(\mathrm{p}=0,006), \mathrm{az}$ interleukin-6 szintje pedig magasabb $(\mathrm{p}=0,05)$ a nem szorongó betegekhez képest. A C-reaktív proteint vizsgálva nem találtak szignifikáns eltérést a két csoport között [38].

A fent említett elméletek felhívják a figyelmet arra, hogy a szorongás - számos egyéb tényező mellett - a cukorbetegség független rizikótényezője lehet, bár további vizsgálatokra van szükség ennek igazolására.

\section{A cukorbetegség hatása a szorongás kialakulására}

Másik irányból vizsgálva a kapcsolatot, a cukorbetegség diagnózisának felállítása stresszt, szorongást okozhat a megváltozott életmód, az egészség feletti ellenőrzés elvesztése miatt. Félelem alakulhat ki a cukorbetegség akut (hypoglykaemia) és krónikus szövődményeitől, illetve a rendszeres injekcióktól [11, 39]. A cukorbetegséggel kapcsolatos napi szintú feladatok (a diéta betartása, gyógyszerszedés, fizikai aktivitás, a dohányzás elhagyása, vércukor-önellenőrzés) is okozhatnak szorongást, ami befolyásolhatja a terápiával való együttmúködést. A fenti szempontokon kívül kiemelendő, hogy az idős betegek esetében fokozhatják a szorongást a pszichoszociális rizikótényezők (például nyugdíjazás, elmagányosodás), a szomatikus és a pszichiátriai komorbid állapotok, illetve a polifarmácia.

Egy 2016-ban megjelent keresztmetszeti tanulmányban a depresszió és a szorongás előfordulását vizsgálták 90686 résztvevő bevonásával, akiket három csoportra osztottak: a) 1-es vagy 2-es típusú diagnosztizált cukorbetegek, b) nem diagnosztizált cukorbetegek, c) nem diabeteses résztvevők. Csak a diagnosztizált cukorbetegek körében volt magasabb a szorongás előfordulási gyakorisága, összehasonlítva a nem cukorbeteg csoporttal $(\mathrm{OR}=1,6 ; \mathrm{CI}: 1,4-1,8)$. A szorongás szignifikánsan gyakoribb volt a diagnosztizált cukorbetegek körében a nem diagnosztizáltakhoz képest $(\mathrm{OR}=1,6$; CI: 1,2$2,1)$. Vizsgálatukkal rávilágítottak arra, hogy a szorongás hátterében a cukorbetegséggel járó betegségteher, a betegség pszichológiai hatása is állhat, amely növeli a szorongásos zavarok előfordulását [40].

Az Amerikai Diabetes Társaság (American Diabetes Association, ADA) az ajánlásában javasolja a depresszió mellett a szorongás szürését is a 21 tételes Beck Szorongás Skálával (Beck Anxiety Inventory, BAI) és a 40 kérdésből álló, önkitöltős Spielberger Állapot- és Vonásszorongás Kérdő́ivvel (Spielberger State and Trait Anxiety Inventory, STAI) [41]. A szorongás súlyosságának becs- 
lésére alkalmas a 14 tételes Hamilton Szorongás Skála is (Hamilton Anxiety Scale, HAM-A) [42].

Fontos megemlíteni a szorongás mellett a pszichológiai distressz fogalmát. Selye János meghatározása alapján a stressz a szervezet nem specifikus válasza a testet ért igénybevételekre. Kétféle stressz létezik: az eustressz, amely pozitív, és a distressz, amely káros vagy kellemetlen stressz [43]. A pszichológiai distressz gyakori a betegek körében, és a betegség diagnózisára, a kezelésre, a tünetekre és a negatív társadalmi megítélésre adott normális válasznak tekinthető. Egy kínai vizsgálat eredményei alapján a pszichológiai distressz szintje emelkedett volt a különböző testi betegségekben szenvedőknél. Hypertonia és hyperlipidaemia esetében 20\%-kal, rákos megbetegedésnél 50\%-kal, myocardialis infarctusnál 60\%-kal, stroke-nál 130\%-kal, diabetes esetében pedig $30 \%$-kal volt gyakoribb a pszichológiai distressz azokhoz viszonyítva, akiknél nem szerepelt az anamnézisben a vizsgált betegség [44].

A distressz következményei kontinuumnak tekinthetők, a mindennapi szomorúságtól és félelemtől olyan problémákig, mint például a depresszió és a szorongás. Ha a szorongás tartóssá válik, részjelenségei önállósulnak, és megfelelő kiváltó ok nélkül vagy a kiváltó okkal nem magyarázható intenzitással és időtartamban jelentkezik, szorongásos betegségről beszélünk [45].

A diabeteses distressz a cukorbetegség és következményei miatt jelentkező komplex jelenség. Jellemző rá a cukorbetegség kezelésétől, rosszabbodásától, illetve a szövődményektől való szorongás, félelem. Egy tanulmány eredménye szerint a vizsgált 2-es típusú cukorbetegek több mint 45\%-ában volt jelen a diabeteses distressz, tehát gyakoribb, mint a depresszió és a szorongás. Fontos felismerni, mert a diabeteses distressz befolyásolja a betegek öngondoskodását, a helyes táplálkozást, a fizikai aktivitást, a terápiával való együttmúködést, és megemeli a hemoglobin-Alc értékét [46].

Számos, pszichológiai distresszt mérő kérdőív létezik. Specifikusan a diabeteses distressz szürésére használható az ADA ajánlása alapján a Problémás Területek a Cukorbetegségben (Problem Areas in Diabetes, PAID) és a Diabetes Distressz Skála (Diabetes Distress Scale, DDS) kérdőív. Ezeket hazánkban még nem validálták [41].

A fentieken kívül a szorongás és a cukorbetegség közti kapcsolat vizsgálatakor mindenképpen figyelembe kell venni, hogy más rizikótényezők is befolyásolhatják a két betegség viszonyát. A szorongásos kórképeknek igen magas a komorbiditásuk más pszichiátriai betegségekkel, a leggyakrabban a depresszióval. Több mint 50\%-ban fordulnak elő együtt. Komorbiditásukkor súlyosabbak a depresszió tünetei, magasabb az öngyilkossági rizikó. A két betegség egymás rizikótényezői: a szorongás hajlamosít depresszió kialakulására, és fordítva, depresszió esetén gyakran alakul ki szorongás. Fontos ezt figyelembe venni, mert ismert, hogy a depresszió önmagában is fokozza a diabetes kialakulásának kockázatát $[47,48]$.

\section{Következtetések}

A szorongás és a cukorbetegség kapcsolata összetett. Több különféle elmélet létezik a leírására: szerepet játszhat benne a közös etiológiai háttér; egyesek szerint a cukorbetegség diagnózisának érzelmi hatása, a gondozással kapcsolatos napi szintü feladatok vezethetnek szorongáshoz; más elméletek szerint pedig a szorongás különböző fiziológiai mechanizmusokon keresztül befolyásolhatja a cukorbetegség kialakulását. A kapcsolat irányától függetlenül fontos mind a két betegséget szűrni és kezelni. A szorongás, a depresszió és a diabeteses distressz között átfedések lehetnek, és egyszerre is elöfordulhatnak. Az alapellátás szintjén annak felismerése a fontos, hogy vannak-e a betegnél a lelki egészséget érintő problémák. Az alapellátásban dolgozók részére kiadott, a 2-es típusú cukorbetegek gondozásáról szóló IDF-ajánlásban szerepel a cukorbetegek pszichológiai eltéréseinek, mint például a depressziónak a szürése [49]. Az ADA ajánlásában a depresszió mellett a szorongás és a diabeteses distressz rendszeres szürésének, diagnózisának és kezelésének fontossága is megjelenik, különösen akkor, ha a kezelési célérték nehezen érhető el [41]. A Magyar Diabetes Társaság Egészségügyi szakmai irányelvében is szerepel a betegedukációról szóló ajánlásban a motiváció és a depressziós jellegü problémák felmérése [50].

A gyakori komorbiditás, valamint az életminőségre, a szomatikus alapbetegségekre, illetve azok hosszú távú kimenetelére és a kezeléssel való együttmúködésre gyakorolt kedvezőtlen hatás miatt fontos a depresszió mellett a szorongás szûrése is a háziorvosi praxisokban a cukorbetegek körében. A korai felismeréssel és kezeléssel javul a glikémiás kontroll, csökken a cukorbetegség szövődményei kialakulásának kockázata, ezáltal javul a betegek életminősége.

Anyagi támogatás: A tanulmány elkészítése anyagi támogatásban nem részesült.

Szerzői munkamegosztás: A szerzők egyenlő arányban vettek részt a közlemény megírásában. A cikk végleges változatát valamennyi szerző elolvasta és jóváhagyta.

Érdekeltségek: A szerzőknek nincsenek érdekeltségeik.

\section{Irodalom}

[1] Faludi G, Gonda X, Döme P. An update on the conceptual and classification issues of anxiety, its neuroanatomy and problems of anxiolytic drug discovery. [A szorongás konceptuális aspektusai, klasszifikációja, neuroanatómiája és az anxiolitikum-fejlesztés problémái.] Neuropsychopharmacol Hung. 2015; 17: 69-80. [Hungarian]

[2] World Health Organization. Depression and Other Common Mental Disorders: Global Health Estimates. WHO, Geneva, 2017. Available from: http://www.who.int/mental_health/ management/depression/prevalence_global_health_estimates/ en/ [accessed: September 10, 2020]. 
[3] Bandelow B, Michaelis S. Epidemiology of anxiety disorders in the 21 st century. Dialogues Clin Neurosci. 2015; 17: 327-335.

[4] Szádóczky E, Rihmer Z, Papp Z, et al. The prevalence of affective and anxiety disorders in primary care practice in Hungary. J Affect Disord. 1997; 43: 239-244.

[5] Wittchen HU, Jacobi F, Rehm J, et al. The size and burden of mental disorders and other disorders of the brain in Europe 2010. Eur Neuropsychopharmacol. 2011; 21: 655-679.

[6] Kroenke K, Spitzer RL, Williams JB, et al. Anxiety disorders in primary care: prevalence, impairment, comorbidity, and detection. Ann Intern Med. 2007; 146: 317-325.

[7] International Diabetes Federation. IDF Diabetes Atlas, 9th edn Brussels, 2019. Available from: https://www.diabetesatlas.org/ en/ [accessed: September 10, 2020].

[8] World Health Organization. Diabetes country profiles 2016 Hungary. WHO, Geneva. Available from: http://www.who. int/diabetes/country-profiles/en/\#H [accessed: September 10, 2020].

[9] Kempler P, Putz Zs, Kiss Z, et al. Prevalence and financial burden of type 2 diabetes mellitus in Hungary between 2001-2014 results of the analysis of the National Health Insurance Fund database. [A 2-es típusú diabetes előfordulása és költségterheinek alakulása Magyarországon 2001-2014 között - az Országos Egészségbiztosítási Pénztár adatbázis-elemzésének eredményei.] Diabetol Hung. 2016; 24: 177-188. [Hungarian]

[10] Jermendy Gy, Kiss Z, Rokszin Gy, et al. Epidemiological data of pharmacologically treated patients with type 2 diabetes registered in a central database in Hungary in 2016. [Antidiabetikummal kezelt 2-es típusú cukorbetegek epidemiológiai adatai Magyarországon 2016-ban - központi regiszter adatbázisának elemzése.] Diabetol Hung. 2019; 27: 205-211. [Hungarian]

[11] Smith KJ, Béland M, Clyde M, et al. Association of diabetes with anxiety: a systematic review and meta-analysis. J Psychosom Res. 2013; 74: 89-99.

[12] Chaturvedi SK, Manche Gowda S, Ahmed HU, et al. More anxious than depressed: prevalence and correlates in a 15 -nation study of anxiety disorders in people with type 2 diabetes mellitus. Gen Psychiatr. 2019; 32: el00076.

[13] Bouwman V, Adriaanse MC, van 't Riet E, et al. Depression, anxiety and glucose metabolism in the general Dutch population: the new Hoorn study. PLoS ONE 2010; 5: e9971.

[14] Degmečić D, Bacun T, Kovač V, et al. Depression, anxiety and cognitive dysfunction in patients with type 2 diabetes mellitus - a study of adult patients with type 2 diabetes mellitus in Osijek, Croatia. Coll Antropol. 2014; 38: 711-716.

[15] Hermanns N, Kulzer B, Krichbaum M, et al. Affective and anxiety disorders in a German sample of diabetic patients: prevalence, comorbidity and risk factors. Diabet Med. 2005; 22: 293-300.

[16] Indelicato L, Dauriz M, Santi L, et al. Psychological distress, selfefficacy and glycemic control in type 2 diabetes. Nutr Metab Cardiovasc Dis. 2017; 27: 300-306.

[17] Lewko J, Zarzycki W, Krajewska-Kułak E. Relationship between the occurrence of symptoms of anxiety and depression, quality of life, and level of acceptance of illness in patients with type 2 diabetes. Saudi Med J. 2012; 33: 887-894

[18] Mikaliūkštienè A, Žagminas K, Juozulynas A, et al. Prevalence and determinants of anxiety and depression symptoms in patients with type 2 diabetes in Lithuania. Med Sci Monit. 2014; 20: 182-190.

[19] Naicker K, Johnson JA, Skogen JC, et al. Type 2 diabetes and comorbid symptoms of depression and anxiety: longitudinal associations with mortality risk. Diabetes Care 2017; 40: 352-358.

[20] Gonda X. The serotonin transporter gene and personality: association of the 5-HTTLPR s allele, anxiety, depression and affective temperaments. [A szerotonintranszporter gén és a személyiség: az 5-HTTLPR s allél, a szorongás, a depresszió és az affektív temperamentumok összefüggése.] Orv Hetil. 2008; 149: 15691573. [Hungarian]
[21] Bagdy Gy. Our genes and mental health. Lesson learned from the relationship between the consequences of stress and the genomics of depression. [Génjeink és a lelki egészség. A stressz hatásának és a depresszió genomikájának összefüggései és tanulságai.] Magy Tud. 2012; 173: 660-672. [Hungarian]

[22] Iordanidou M, Tavridou A, Petridis I, et al. The serotonin trans porter promoter polymorphism (5-HTTLPR) is associated with type 2 diabetes. Clin Chim Acta 2010; 411: 167-171.

[23] Hameed A, Ajmal M, Nasir M, et al. Genetic association analysis of serotonin transporter polymorphism (5-HTTLPR) with type 2 diabetes patients of Pakistani population. Diabetes Res Clin Pract. 2015; 108: 67-71.

[24] Peralta-Leal V, Leal-Ugarte E, Meza-Espinoza JP, et al. Association of a serotonin transporter gene (SLC6A4) 5-HTTLPR polymorphism with body mass index categories but not type 2 diabetes mellitus in Mexicans. Genet Mol Biol. 2012; 35: 589593.

[25] Miyata S, Yamada N, Hirano S, et al. Diabetes attenuates psychological stress-elicited 5-HT secretion in the prefrontal cortex but not in the amygdala of mice. Brain Res. 2007; 1147: 233-239.

[26] Wilhelm K, Gillis I, Reddy J, et al. Association between serotonin transporter promoter polymorphisms and psychological distress in a diabetic population. Psychiatry Res. 2012; 200: 343-348.

[27] Agardh E, Allebeck P, Hallqvist J, et al. Type 2 diabetes incidence and socio-economic position: a systematic review and meta-analysis. Int J Epidemiol. 2011; 40: 804-818.

[28] Baum A, Garofalo JP, Yali AM. Socioeconomic status and chronic stress. Does stress account for SES effects on health? Ann N Y Acad Sci. 1999; 896: 131-144.

[29] Smith KJ, Deschênes SS, Schmitz N. Investigating the longitudinal association between diabetes and anxiety: a systematic review and meta-analysis. Diabet Med. 2018; 35: 677-693

[30] Bonnet F, Irving K, Terra J-L, et al. Anxiety and depression are associated with unhealthy lifestyle in patients at risk of cardiovascular disease. Atherosclerosis 2005; 178: 339-344.

[31] Jansson-Fröjmark M, Lindblom K. A bidirectional relationship between anxiety and depression, and insomnia? A prospective study in the general population. J Psychosom Res. 2008; 64: 443-449.

[32] Gariepy G, Nitka D, Schmitz N. The association between obesity and anxiety disorders in the population: a systematic review and meta-analysis. Int J Obes. 2010; 34: 407-419.

[33] van Dam RM. The epidemiology of lifestyle and risk for type 2 diabetes. Eur J Epidemiol. 2003; 18: 1115-1125.

[34] Anothaisintawee T, Reutrakul S, van Cauter E, et al. Sleep disturbances compared to traditional risk factors for diabetes development: systematic review and meta-analysis. Sleep Med Rev. 2016; 30: 11-24.

[35] Chrousos GP. The role of stress and the hypothalamic-pituitaryadrenal axis in the pathogenesis of the metabolic syndrome: neuro-endocrine and target tissue-related causes. Int $\mathrm{J}$ Obes Relat Metab Disord. 2000; 24(Suppl 2): S50-S55.

[36] Tian R, Hou G, Li D, et al. A possible change process of inflammatory cytokines in the prolonged chronic stress and its ultimate implications for health. Scientific World J. 2014; 2014: 780616.

[37] Pickup JC, Crook MA. Is type II diabetes mellitus a disease of the innate immune system? Diabetologia 1998; 41: 1241-1248.

[38] O'Donovan A, Hughes BM, Slavich GM, et al. Clinical anxiety, cortisol and interleukin-6: evidence for specificity in emotionbiology relationships. Brain Behav Immun. 2010; 24: 10741077.

[39] Pouwer F. Should we screen for emotional distress in type 2 diabetes mellitus? Nat Rev Endocrinol. 2009; 5: 665-671.

[40] Meurs M, Roest AM, Wolffenbuttel BH, et al. Association of depressive and anxiety disorders with diagnosed versus undiagnosed diabetes: an epidemiological study of 90,686 participants. Psychosom Med. 2016; 78: 233-241. 
[41] Young-Hyman D, de Groot M, Hill-Briggs F, et al. Psychosocial care for people with diabetes: a position statement of the American Diabetes Association. Diabetes Care 2016; 39: 2126-2140.

[42] Hamilton $\mathrm{M}$. The assessment of anxiety states by rating. $\mathrm{Br} \mathrm{J}$ Med Psychol. 1959; 32: 50-55.

[43] Selye J. Stress without distress. [Stressz distressz nélkül.] Akadémiai Kiadó, Budapest, 1976. [Hungarian]

[44] Nakaya N, Kogure M, Saito-Nakaya K, et al. The association between self-reported history of physical diseases and psychological distress in a community-dwelling Japanese population: the Ohsaki Cohort 2006 Study. Eur J Public Health 2014; 24: 45-49.

[45] Radics J. Anxiety-solving as an essential ingredient for the treatment. [Szorongásoldás mint a gyógyítás nélkülözhetetlen kelléke.] Orv Hetil. 2014; 155: 859-864. [Hungarian]

[46] Fisher L, Hessler DM, Polonsky WH, et al. When is diabetes distress clinically meaningful? Establishing cut points for the Diabetes Distress Scale. Diabetes Care 2012; 35: 259-264.

[47] Jacobson NC, Newman MG. Anxiety and depression as bidirectional risk factors for one another: a meta-analysis of longitudinal studies. Psychol Bull. 2017; 143: 1155-1200.
[48] Hargittay Cs, Márkus B, Vörös K, et al. Co-occurrence of diabetes and depression, their potential bidirectional association and the significance of their screening. [A diabetes és a depresszió együttes előfordulása, lehetséges kétirányú kapcsolata és szűrésük jelentősége.] Orv Hetil. 2019; 160: 807-814. [Hungarian]

[49] International Diabetes Federation. Recommendations for managing type 2 diabetes in primary care. IDF, Brussels, 2017. Available from: https://www.idf.org/managing-type2-diabetes [accessed: December 10, 2020].

[50] Karádi I, Jermendy Gy, Gaál Zs, et al. Clinical practice guideline - Diagnosis of diabetes, and antihyperglycaemic treatment and care of patients with diabetes in adulthood. [Egészségügyi szakmai irányelv - A diabetes mellitus kórismézéséről, a cukorbetegek antihyperglykaemiás kezeléséról és gondozásáról felnőttkorban.] Diabetol Hung. 2020; 28(3): 119-204.

(Hargittay Csenge dr., Budapest, Pf. 2, 1428. e-mail: hargittay.csenge@med.semmelweis-univ.hu)

\section{„Experto credite!" (Vergilius) (Higgyetek a szakembereknek!)}

A cikk a Creative Commons Attribution 4.0 International License (https://creativecommons.org/licenses/by/4.0/) feltételei szerint publikált Open Access közlemény, melynek szellemében a cikk bármilyen médiumban szabadon felhasználható, megosztható és újraközölhető, feltéve, hogy az eredeti szerző és a közlés helye, illetve a CC License linkje és az esetlegesen végrehajtott módositások feltüntetésre kerülnek. (SID_1) 